Original Research Article

\title{
Comparative study of centrally acting skeletal muscle relaxants nitrazepam and thiocolchicoside in Albino mice
}

\author{
Suresh Babu Sayana ${ }^{1}$, Yamuna Sampathirao², Baswaraj Munge ${ }^{1 *}$, \\ Sachidananda Moorthy ${ }^{1}$, Kodandaramu Burli ${ }^{1}$
}

${ }^{1}$ Department of Pharmacology, ${ }^{2}$ MBBS Student, Maharajah's Institute of Medical Sciences, Nellimarla, Vizianagaram, Andhra Pradesh, India

Received: 05 April 2018

Revised: 13 April 2018

Accepted: 01 May 2018

*Correspondence to:

Dr. Baswaraj Munge,

Email: mungembbs@gmail.com

Copyright: () the author(s), publisher and licensee Medip Academy. This is an openaccess article distributed under the terms of the Creative Commons Attribution NonCommercial License, which permits unrestricted noncommercial use, distribution, and reproduction in any medium, provided the original work is properly cited.

\begin{abstract}
Background: Skeletal muscle relaxants are a heterogeneous group of drugs. As a group, they are structurally and pharmacologically diverse. Skeletal muscle relaxants are usually used as adjunct therapy when initial therapy fails. They are commonly used to treat fibromyalgia, low back pain, neck pain, tension head ache, myofascial pain and muscle spasm.

Methods: There were 28 mice were randomly divided into seven groups, each group consists of 4 mice. Group 1(Control): Mice were treated with normal saline and placed on rotating rod with a speed of $18 \mathrm{rpm}$ (ideal speed). Group 2 (Standard-S1): Mice were treated with Nitrazepam at the dose of $2 \mathrm{mg} / \mathrm{kg}$ body weight and placed on rotating rod. Group 3 (Standard-S2): Mice were treated with Nitrazepam at the dose of $3 \mathrm{mg} / \mathrm{kg}$ body weight and placed on rotating rod. Group 4 (Standard-S3): Mice were treated with Nitrazepam at the dose of $4 \mathrm{mg} / \mathrm{kg}$ body weight and placed on rotating rod. Group 5 (Test-T1): Mice were treated with Thiocolchicoside at the dose of $2 \mathrm{mg} / \mathrm{kg}$ body weight and placed on rotating rod. Group 6 (Test-T2): Mice were treated with Thiocolchicoside at the dose of $3 \mathrm{mg} / \mathrm{kg}$ body weight and placed on rotating rod. Group 7 (Test-T3): Mice were treated with Thiocolchicoside at the dose of $4 \mathrm{mg} / \mathrm{kg}$ body weight and placed on rotating rod.

Results: In this model inter drug comparisons were carried out with nitrazepam and thiocolchicoside. It was found that both nitrazepam and thiocolchicoside produced central muscle relaxant effect when assessed by rotarod. On iter drug comparision of nitrazepam and thiocolchicoside it was found that by increasing concentration of drug, increased the muscle relaxant property.

Conclusions: When assessed by rotarod, it was found that both nitrazepam and thiocolchicoside demonstrated muscle relaxant property but with increased doses of thiocolchicoside produced more muscle relaxant property than the increase in doses of nitrazepam.
\end{abstract}

Keywords: Muscle relaxant, Mice, Nitrazepam, Rotarod, Thiocolchicoside

\section{INTRODUCTION}

Skeletal muscle relaxants are a heterogeneous group of drugs. As a group, they are structurally and pharmacologically diverse. ${ }^{1}$ Skeletal muscle relaxants are usually used as adjunct therapy when initial therapy fails. They are commonly used to treat fibromyalgia, low back pain, neck pain, tension head ache, myofascial pain and muscle spasm. Increased muscle tone is a common feature of anxiety states in humans and may contribute to the aches and pains including head ache that often trouble anxious patients. $^{2}$ The relaxant effect of benzodiazepines may therefore be clinically useful. Benzodiazepines reduce muscle tone by a central action that is independent of their sedative effect. Cats are particularly sensitive to this action and some benzodiazepines like Diazepam, clonazepam, 
nitrazepam, flunitrazepam reduce decerebrate rigidity in doses that are much smaller than those needed to produce behavioural effects. ${ }^{3}$ In other species the difference is less clear, coordination can be tested by measuring the length of time for which mice can stay on a slowly rotating horizontal plastic rod. Nitrazepam is a benzodiazepine having muscle relaxant property but much studies are not available for its muscle relaxant property. Thiocolchicoside is a colchicoside derivative commonly used muscle relaxant for the treatment of various spastic conditions. Hence the present study is undertaken to evaluate and compare the centrally acting skeletal muscle relaxant property of nitrzepam and thiocolchicoside in albino mice.

Muscle relaxant is a drug which effects skeletal muscle function and decreases the muscle tone. It may be used to alleviate symptoms such as muscle spasm, pain and hyperreflexia. ${ }^{4}$ Skeletal muscle relaxants act directly at the level of cerebro-spinal axis and cause relaxation of skeletal muscles. They reduce muscle tone, stiffness, exaggerated tendon reflexes, involuntary movements and spasms in a diverse variety of conditions including multiple sclerosis, cerebral palsy, spinal cord injuries, traumatic brain injury. ${ }^{5}$ Skeletal muscle relaxants are used to treat two different underlying conditions, spasticity from upper motor neuron, muscular pain or spasm from peripheral musculo skeletal conditions.

Similar comparative studies were conducted and published to compare skeletal muscle relaxant property of various drugs. These include comparative study of centrally acting skeletal muscle relaxants diazepam and thiocolchicoside in albino mice. ${ }^{6}$ Skeletal muscle relaxant property of diazepam by using rotarod on albino mice. ${ }^{7}$ Evaluation of centrally acting skeletal muscle relaxant activity of aqueous extract of Cinnamomum zeylanicum bark in albino mice. ${ }^{8}$

\section{METHODS}

Drugs and solutions were used in the study was Nitrazepam (10mg), Thiocolchicoside (4mg/2ml), Distilled water, Normal saline.

\section{Equipment}

Rota rod, insulin syringes, measuring jar, glass beakers, animal weighing balance, animal cages, cotton, spirit were the Equipment which was used in the study.

\section{Animals}

There were 28 Albino mice of either sex weighing $30 \mathrm{~g}$ were used for this study. ${ }^{5}$ Animals were maintained under standard husbandry conditions. The experimental protocol was approved by the Institutional Animal Ethics Committee (IAEC) of Maharajah's Institute of Medical Sciences. Study period was from 15 June 2017 to 14 august 2017. This study was conducted in Department of
Pharmacology, Maharajah's Institute of Medical Sciences, Nellimarla, Vizianagaram, Andhra Pradesh.

\section{Experimental design}

\section{Rota rod model}

The apparatus used for evaluation and comparison of muscle relaxant property is rota rod. ${ }^{9,10}$ The rota rod assembly is immensely useful for screening drugs effecting motor coordination. ${ }^{6,7}$ It consists of four experimental compartments with a rotating rod of about 25 $\mathrm{mm}$ diameter and having speeds of approximately 5,10 , $15,20,25$ revolutions $/ \mathrm{min}$. Time intervals are provided in each compartment. 28 mice were randomly divided into seven groups, each group consists of 4 mice.

- $\quad$ Group 1 (Control): Mice were treated with normal saline and placed on rotating rod with a speed of 18 rpm (ideal speed).

- Group 2 (Standard-S1): Mice were treated with Nitrazepam at the dose of $2 \mathrm{mg} / \mathrm{kg}$ body weight and placed on rotating rod.

- Group 3 (Standard-S2): Mice were treated with Nitrazepam at the dose of $3 \mathrm{mg} / \mathrm{kg}$ body weight and placed on rotating rod

- Group 4 (Standard-S3): Mice were treated with Nitrazepam at the dose of $4 \mathrm{mg} / \mathrm{kg}$ body weight and placed on rotating rod

- Group 5 (Test-T1): Mice were treated with Thiocolchicoside at the dose of $2 \mathrm{mg} / \mathrm{kg}$ body weight and placed on rotating rod.

- Group 6 (Test-T2): Mice were treated with Thiocolchicoside at the dose of $3 \mathrm{mg} / \mathrm{kg}$ body weight and placed on rotating rod

- Group 7 (Test-T3): Mice were treated with Thiocolchicoside at the dose of $4 \mathrm{mg} / \mathrm{kg}$ body weight and placed on rotating rod.

\section{Statistical analysis}

The result was expressed as mean+SEM. Statistical analysis was performed by using unpaired student $t$ - test. $\mathrm{P}<0.05$ was considered statistically significant.

\section{RESULTS}

The study was performed in albino mice having the weight of $30 \mathrm{~g}$. In each group four albino mice were included for the evaluation and comparison of the muscle relaxant property of both nitrazepam and thiocolchicoside in various concentrations such as 2,3 and $4 \mathrm{mg} / \mathrm{kg}$.

Albino mice is one of the best animal for initial screening of any drug as it is easy to hold and can be used repetitively since the mice is not sacrificed by rota rod method. Albino rat is the second choice of animal for this type of experiments. In this present experiment it was found that the percentage of fall of free ride time for Nitrazepam is 
$7.22,11.35$ and 23.37 with $2 \mathrm{mg} / \mathrm{kg}, 3 \mathrm{mg} / \mathrm{kg}$, and $4 \mathrm{mg} / \mathrm{kg}$ respectively (Table 1$)$. Whereas for thiocolchicoside it is
$17.49,34.92$ and 38.47 with $2 \mathrm{mg} / \mathrm{kg}, 3 \mathrm{mg} / \mathrm{kg}$ and $4 \mathrm{mg} / \mathrm{kg}$ respectively (Table 2 ) when assessed by rota rod method.

Table 1: Treatment with Nitrazepam at the dose of $2,3,4 \mathrm{mg} / \mathrm{kg}$ body weight.

\begin{tabular}{|c|c|c|c|c|c|c|c|c|c|c|c|}
\hline \multirow{4}{*}{$\begin{array}{l}\text { Body wt. } \\
\text { in gm } \\
\text { (Mice) }\end{array}$} & \multicolumn{8}{|c|}{ Fall of Free ride time } & \multirow{2}{*}{\multicolumn{3}{|c|}{$\%$ fall of free ride time }} \\
\hline & \multirow{2}{*}{\multicolumn{2}{|c|}{$\begin{array}{l}\text { Normal Saline } \\
0.2 \mathrm{ml}\end{array}$}} & \multicolumn{6}{|c|}{ Nitrazepam } & & & \\
\hline & & & $2 \mathrm{mg} / \mathrm{kg}$ & & $3 \mathrm{mg} / \mathrm{kg}$ & & $4 \mathrm{mg} / \mathrm{kg}$ & & \multirow{2}{*}{$2 \mathrm{mg} / \mathrm{kg}$} & \multirow{2}{*}{$3 \mathrm{mg} / \mathrm{kg}$} & \multirow{2}{*}{$4 \mathrm{mg} / \mathrm{kg}$} \\
\hline & Before & After & Before & After & Before & After & Before & After & & & \\
\hline 30 & 272 & 275 & 278 & 253 & 283 & 246 & 271 & 208 & 8.99 & 13.07 & 23.25 \\
\hline 30 & 249 & 266 & 251 & 242 & 241 & 229 & 263 & 197 & 3.59 & 4.98 & 25.10 \\
\hline 30 & 280 & 279 & 238 & 228 & 253 & 206 & 248 & 203 & 4.20 & 18.58 & 18.15 \\
\hline 30 & 276 & 254 & 297 & 261 & 284 & 259 & 289 & 211 & 12.12 & 8.80 & 26.99 \\
\hline
\end{tabular}

Table 2: Treatment with Thiocolchicoside at the dose of $2,3,4 \mathrm{mg} / \mathrm{kg}$ body weight.

\begin{tabular}{|c|c|c|c|c|c|c|c|c|c|c|c|}
\hline \multirow{4}{*}{$\begin{array}{l}\text { Body wt. } \\
\text { in gm } \\
\text { (Mice) }\end{array}$} & \multicolumn{8}{|c|}{ Fall of Free ride time } & \multirow{2}{*}{\multicolumn{3}{|c|}{$\%$ fall of free ride time }} \\
\hline & \multirow{2}{*}{\multicolumn{2}{|c|}{$\begin{array}{l}\text { Normal Saline } \\
0.2 \mathrm{ml}\end{array}$}} & \multicolumn{6}{|c|}{ Thiocolchicoside } & & & \\
\hline & & & $2 \mathrm{mg} / \mathrm{kg}$ & & $3 \mathrm{mg} / \mathrm{kg}$ & & $4 \mathrm{mg} / \mathrm{kg}$ & & \multirow{2}{*}{$2 \mathrm{mg} / \mathrm{kg}$} & \multirow{2}{*}{$3 \mathrm{mg} / \mathrm{kg}$} & \multirow{2}{*}{$4 \mathrm{mg} / \mathrm{kg}$} \\
\hline & Before & After & Before & After & Before & After & Before & After & & & \\
\hline 30 & 272 & 275 & 269 & 214 & 263 & 173 & 273 & 178 & 20.45 & 34.22 & 34.80 \\
\hline 30 & 249 & 266 & 294 & 223 & 289 & 186 & 271 & 168 & 24.15 & 35.64 & 38.01 \\
\hline 30 & 280 & 279 & 273 & 215 & 259 & 160 & 268 & 152 & 21.25 & 38.22 & 43.28 \\
\hline 30 & 276 & 254 & 243 & 233 & 291 & 199 & 275 & 171 & 4.12 & 31.62 & 37.82 \\
\hline
\end{tabular}

The percentage of fall of free ride time for nitrazepam is 7.22 , at $2 \mathrm{mg} / \mathrm{kg}$ dose whereas for thiocolchicoside, it is 17.49. At this concentration the difference is high for nitrazepam and thiocolchicoside. The unpaired student $t$ test result is highly significant for these drugs. This study shows that thiocolchicoside is more potent than nitrazepam at this concentration and it reduces the muscle grip property is more than the nitrazepam.

The percentage of fall of free ride time for nitrazepam is 11.35 , at $3 \mathrm{mg} / \mathrm{kg}$ dose whereas for thiocolchicoside, it is 34.92. At this concentration the difference is high for nitrazepam and thiocolchicoside. The unpaired student $t$ test result is highly significant for these drugs. This study shows that thiocolchicoside is more potent than nitrazepam at this concentration and it reduces the muscle grip property is more than the nitrazepam.

The percentage of fall of free ride time for nitrazepam is 23.37 at $3 \mathrm{mg} / \mathrm{kg}$ dose whereas for thiocolchicoside, it is 38.47. At this concentration the difference is high for nitrazepam and thiocolchicoside. The unpaired student $\mathrm{t}$ test result is highly significant for these drugs. This study shows that thiocolchicoside is more potent than nitrazepam at this concentration and it reduces the muscle grip property is more than the nitrazepam.

\section{DISCUSSION}

Earlier experimental studies suggested that the non specific muscle relaxant effect and CNS depression can decrease the response of motor activity. Increased muscle tone is a regular feature of anxiety states in human beings and may contribute to the aches and pains including headache that often trouble anxious patients. ${ }^{10}$ Therefore the muscle relaxant effect of benzodiazepines may be useful clinically. A reduction of muscle tone appears to be possible without appreciable loss of coordination. Skeletal muscle relaxants are used to treat two different types of conditions 1) spasticity from upper motor neuron syndromes 2) muscular pains or spasms from peripheral musculoskeletal conditions. In this study centrally acting skeletal muscle relaxants nitrazepam and thiocolchicoside were used and muscle relaxant activity of thiocolchicoside is compared with nitrazepam. ${ }^{4}$ This study shows at all concentrations thiocolchicoside reduces muscle grip property is more than nitrazepam. So Thiocolchicoside is very potent than nitrazepam in exhibiting muscle relaxant property.

The present experimental study was carried out to evaluate and compare the central muscle relaxant property of nitrazepam and thiocolchicoside in different concentrations in experimental model. The experimental model is rota rod test in albino mice. Both Nitrazepam and thiocolchicoside were given in concentrations of $2 \mathrm{mg} / \mathrm{kg}$, $3 \mathrm{mg} / \mathrm{kg}$ and $4 \mathrm{mg} / \mathrm{kg}$ body weight in rota rod method for each mouse in each group respectively.

It was found that both nitrazepam and thiocolchicoside produced central muscle relaxant effect when assessed by rota rod test. On inter drug comparison of nitrazepam and thiocolchicoside it was found that by increasing 
concentration of drug, increased the muscle relaxant property, when assessed by rota rod.

Thus, it can conclude that nitrazepam and thiocolchicoside demonstrated central muscle relaxant property but with increased doses of thicolchicoside produced more muscle relaxant property than increase in doses of nitrazepam.

\section{ACKNOWLEDGEMENTS}

The authors are grateful to ICMR for approving this project ICMR STS-2017. The authors would also thankful to the management of maharajah's institute of medical sciences for providing facilities to carry out this project successfully.

Funding: No funding sources

Conflict of interest: None declared

Ethical approval: The study was approved by the Institutional Animal Ethics Committee

\section{REFERENCES}

1. Ghosh MN. Fundamentals of Experimental Pharmacology, $2^{\text {nd }}$ edition, Scientific book agency, Kolkata; 2008:156.

2. Rang HP, Dale MM, Ritter JM, Flower RJ. Henderson G. Pharmacology, $8^{\text {th }}$ ed, Elsevier; 2013:535.

3. Katzung BG, Masters SB, Trevor AJ. Bas and Cli Pharmac. $12^{\text {th }}$ ed, Lange; 2012:379.
4. Tripathi KD. Essentials of medical pharmacology, Jaypee Brothers, New Delhi, $5^{\text {th }}$ edition; 2010:339.

5. Sharma HL, Sharma KK. Pinciples of Pharmacology, Paras medical publishers, Hyderabad, $2^{\text {nd }}$ edition; 2012:197.

6. Kumar NS, Addepalli SK, Sayana SB, Kanuparthi SR, Christina, Medabala T. Comparative study of centrally acting skeletal muscle relaxants diazepam and thiocolchicoside in albino mice. Asian $\mathbf{J}$ Biochem Pharm Res. 2013;3(4):9-14.

7. Veena SN, Sivaji K, Benerji GV, Babu MF, Kumari DR. Skeletal muscle property of diazepam by using rotarod on albino mice. Ind J Bas Appl Med Res. 2015;4(4):714-21.

8. Jayasree T, Kavitha R, Chandrasekhar N, Saequa S. Evaluation of centrally acting skeletal muscle relaxant activity of aqueous extract of Cinnamomum zeylanicum bark in albino mice. J NTR Univ Health Sci. 2012;1(2):94-8.

9. Kulakarni SK. Hand book of Experimental pharmacology, $3^{\text {rd }}$ ed, Vallabh publications; 2012:122.

10. Devi SJ. Experimental Pharmacology, $1^{\text {st }}$ ed, Jaypee; 2013:122.

Cite this article as: Sayana SB, Sampathirao Y, Munge B, Moorthy S, Burli K. Comparative study of centrally acting skeletal muscle relaxants nitrazepam and thiocolchicoside in Albino mice. Int $\mathrm{J}$ Basic Clin Pharmacol 2018;7:1182-5. 